\title{
Light- and electron-microscopic observations on the relationship between prelampbrush oocytes and surrounding granulosa cells in the laying Japanese quail (Coturnix coturnix japonica)
}

\author{
M Callebaut \\ RUCA, Laboratory of Human Anatomy and Embryology, Groenenborgerlaan 171, \\ 2020 Antwerpen, Belgium
}

(Received 9 September 1990; accepted 3 May 1991)

\begin{abstract}
Summary - Transmission electronmicroscopic (TEM) observations demonstrated that the most superficial region of quail oocytes during the prelampbrush stage differs locally from the deeper ooplasm and is an active zone which forms exooplasmic cones, ridges or knob-like protrusions in the direction of/or in the granulosa cells. This exooplasm, in which no mitochondria were seen, is separated from the endooplasm, by a narrow interrupted filamentous layer. Using a lipid-preserving method of fixation, morphological evidence was found for the transport of lipid material from the granulosa cells into the exooplasm of the oocyte. Open intercellular bridges between exooplasm and granulosa cell cytoplasm were also seen. Differences between the electronmicroscopic aspect of clear and dark granulosa cells have been described.
\end{abstract}

Japanese quail / prelampbrush oocyte / avian ovarian granulosa cell / ooplasm / lipid

Résumé - Étude avec le microscope photonique et électronique des relations existant entre l'oocyte (avant le stade en écouvillon) de caille et les cellules de la granulosa quil l'entourent. A l'aide du microscope électronique, nous avons observé que l'ooplasme le plus superficiel a une structure qui diffère localement de l'ooplasme plus profond. L'ooplasme superficiel forme par endroits des cônes ou crêtes d'exooplasme dirigées vers ou dans les cellules de la granulosa. L'exooplasme ne contient pas de mitrochondries et est séparé de l'endooplasme par une mince couche filamenteuse interrompue, visible après l'emploi d'un fixateur qui préserve bien les lipides. Nos observations suggèrent que du matériel lipidique provenant du cytoplasme des cellules de la granulosa est transporté vers l'exooplasme. De plus, l'exooplasme présente localement des ponts intercellulaires ouverts en communication directe avec le cytoplasme des cellules de la granulosa. Les différences d'ordre ultrastructural entre les cellules claires et foncées de la granulosa sont décrites.

caille japonaise / oocyte prelampbrush / cellule de la granulosa ovarienne / ooplasme / lipide 


\section{INTRODUCTION}

In vertebrates the function of the granulosa cells surrounding the oocyte is not completely understood and also differs widely according to the developmental stage of the follicle. Electronmicroscopic observations have demonstrated that in sauropsidian follicles the morphology of the granulosa cells is typical of that of biosynthetically active secretory cells owing to the presence of abundant rough endoplasmic reticulum, Golgi complexes and mitochondria, especially during the early stages of intrafollicular development (Bellairs, 1965; Wyburn et al, 1966; Rahil and Narbaitz, 1973; Klosterman, 1987). The transfer of organelles (transosomes or lining bodies) from the granulosa cells into the oocyte has been observed both in birds (Press, 1964; Bellairs, 1965; Wyburn et al, 1966) and in chelonians (Rahil and Narbaitz, 1973).

In the present work, transmission electron microscopy (TEM) was used to study the relationship between the quail prelampbrush oocyte and the surrounding granulosa cells. The term prelampbrush stage was used (Callebaut, 1973) and not Balbiani or dispersed Balbiani stage as used by Bellairs (1967) since we have shown by appropriate fixation methods (Callebaut, 1984) that part of the elements from the Balbiani complex persist in their paranuclear position for a much longer period than is usually assumed. Indeed, its presence near the germinal vesicle can still be demonstrated during at least the entire phase $I$ of the ensuing lampbrush stage (in quail oocytes with a diameter of $\approx$ $700 \mu \mathrm{m})$.

In the present study we provide evidence that there exist important interactions between the superficial ooplasm (called exooplasm) and the granulosa cell cytoplasm.

\section{MATERIALS AND METHODS}

After decapitation of laying Japanese quail (Coturnix coturnix japonica) and opening of their abdomen, pieces of ovary were removed and fixed in $1 \%$ glutaraldehyde in $0.05 \mathrm{M}$ sodium cacodylate buffer containing $0.01 \%$ malachite green, according to the procedure of Lawton (1989). After $2 \mathrm{~h}$ fixation the pieces were (without rinsing) either placed directly in $70 \%$ alcohol for $3 \mathrm{~h}$ (fixation method 1) or directly in $1 \%$ aqueous osmium tetroxide for $1 \mathrm{~h}$ (fixation method 2).

After fixation method 1 , the pieces were passed through $50 \%$ alcohol $(3 \mathrm{~h}), 30 \%$ alcohol $(3 \mathrm{~h})$, tap water during 1 night and then also postfixed in $1 \%$ aqueous osmium tetroxide for 1 h. After rinsing in tap water, the tissues (both from methods 1 and 2) were posttixed in $2 \%$ aqueous uranyl acetate $(1 \mathrm{~h})$, followed by rinsing in tap water. For light microscopic studies, the tissues were dehydrated in alcohol and embedded in paraffin or glycol methacrylate. Eight$\mu \mathrm{m}$ thick paraffin sections and $1-\mu \mathrm{m}$ thick glycol methacrylate sections were made. For electron microscopic studies, the tissues were dehydrated in alcohol and infiltration and embedding was performed via propylene oxide into $L X-112$ Resin (Ladd).

The ultrathin sections made with an LKB ultratome were stained with $10 \%$ uranyl acetate in methanol for $7 \mathrm{~min}$, followed by staining with lead citrate (Reynolds, 1963). The ultrathin sections were then studied with a transmission electron microscope (Siemens Elmiscop 101).

\section{RESULTS}

\section{Light microscopic observations}

After fixation method 1 , besides the intraoocytal lipid spherules around the Balbiani complex and germinal vesicle, numerous groups of lipid spherules (of similar size) were seen in the granulosa layer (fig 1). However, on the paraffin sections it was not always clear whether the lipid spherules were localized in the granulosa cells 


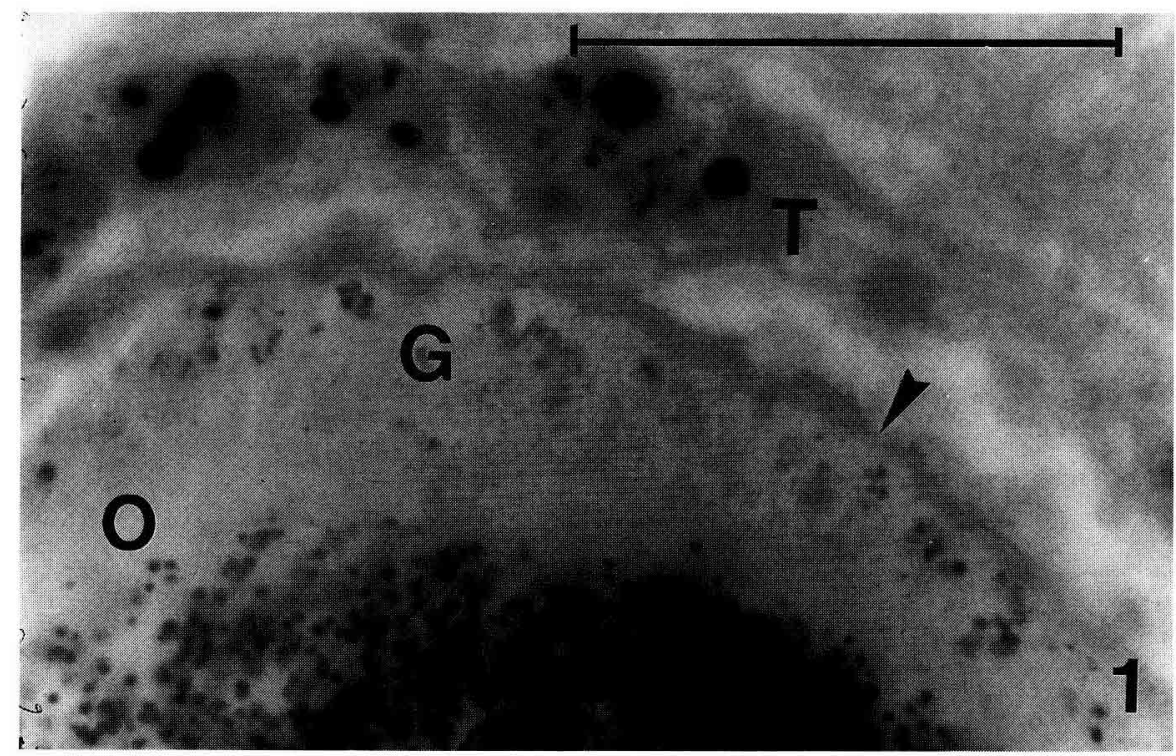

Fig 1. Micrograph of undeparaffinized section through quail follicle containing an oocyte in prelampbrush stage; G: granulosa layer containing numerous groups of lipid granules with the same diameter as those seen in the ooplasm (O); T: theca with large lipid inclusions; arrowhead indicates basement membrane; fixation: glutaraldehyde malachite green $-70 \%$ alcohol- osmium tetroxide. Scale bar: 50 $\mu \mathrm{m}$.

or between them. After glycol methacrylate embedding, no lipid inclusions were visible in the granulosa layer, indicating that they had been solubilized by the histological procedure.

\section{Transmission electron microscopic observations}

With fixation method 1 the lipids were well conserved, also at the electron microscopic level. The superficial ooplasm was seen to form different kinds of exooplasmic extensions in the direction of/or in the granulosa cells. The first type was seen to point to the junction of 2 granulosa cells and often had the form of a cone or ridge with a broad base (fig 2). The exooplasmic areas were incompletely separated from the remainder of the ooplasm by a nearly plane region of filaments (probably actin bundles). By contrast to the underlying endooplasm, no mitochondria were seen in the exooplasmic cones (fig 2). The latter contain groups of lipoid elements localized below intercellular communications between a granulosa cell and the exooplasm. Bellairs (1967) described them on a drawing as pinocytotic-like vesicles, since by her fixation and embedding method the lipoid material was probably solubilized. Sometimes globular material seems to be in the process of expulsion by the granulosa cell cytoplasm in the direction of the exooplasm (fig 3). 

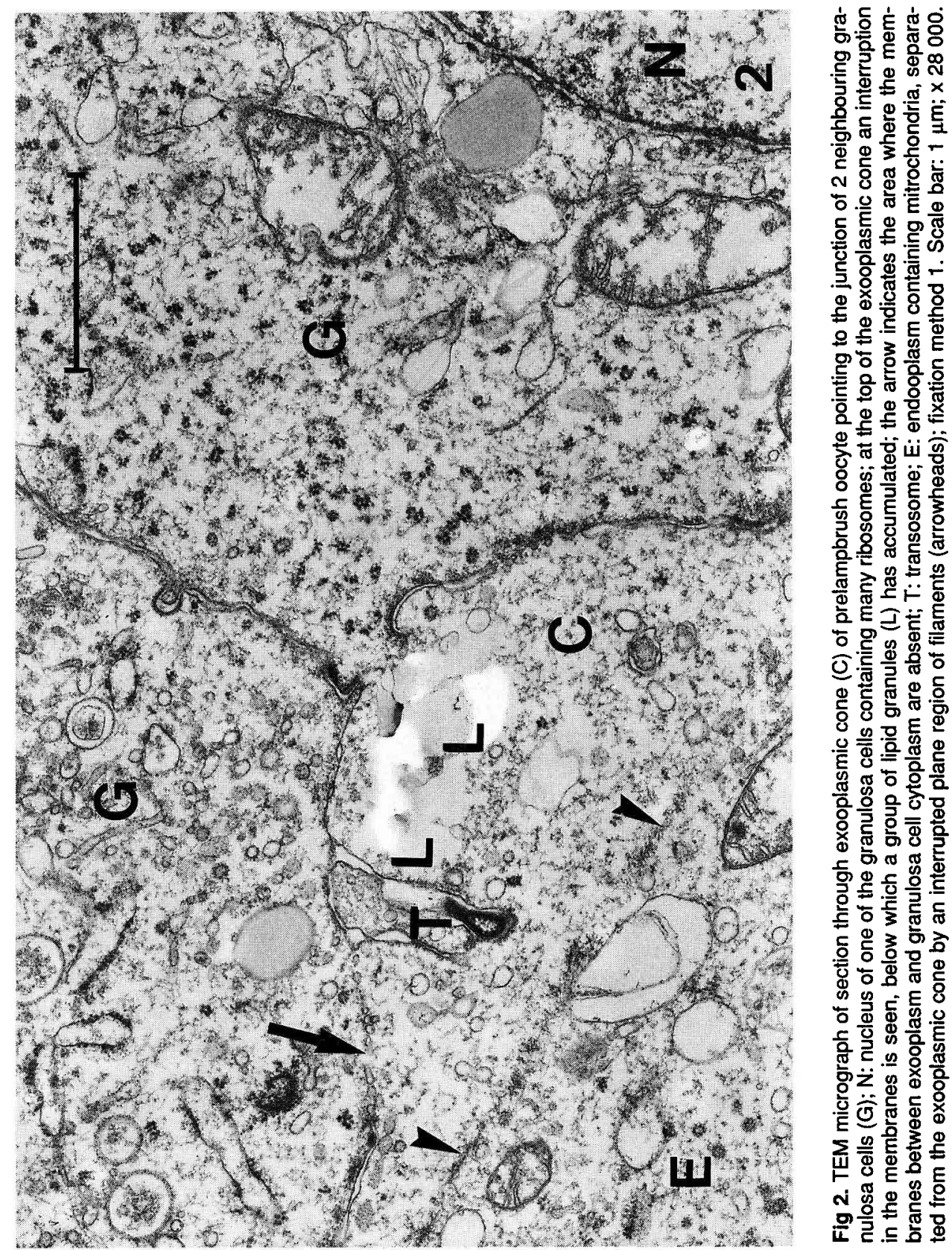


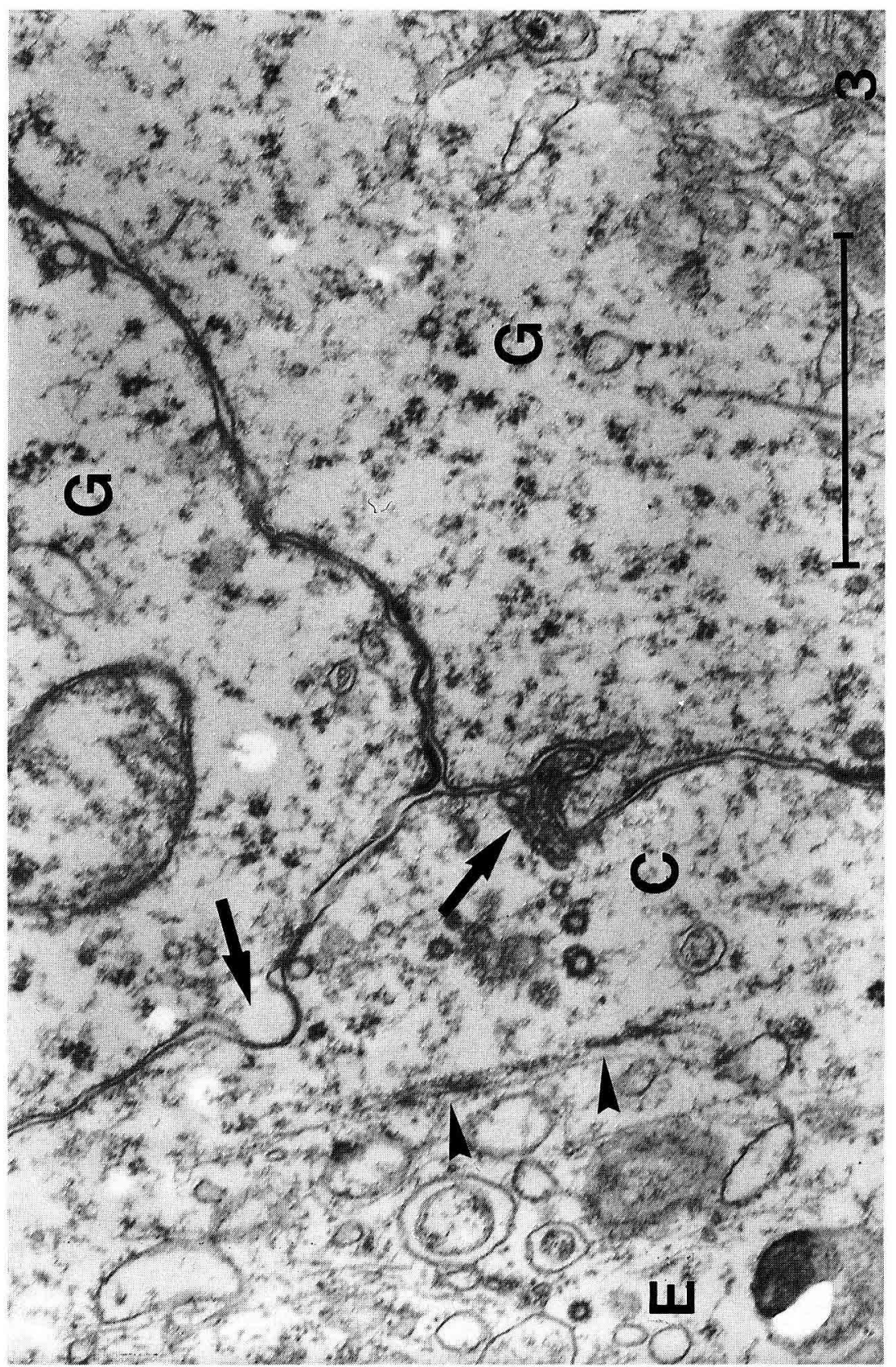

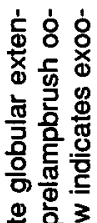

흔흐은

产

응응으

0 응

응

늘 计

芯必

ㄴ.

들

을

.

$\stackrel{0}{\equiv}$

으융

잉

들 을

을웡요

을

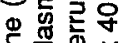

응.

응흥

해용

증 형

종윽 을 몽

责究的

혼흥․

을잉잉

들은 혼

$\Phi$ 흥으.

生完焉

동

웅응응

항

응 응

옹흘

$\Sigma$ ग

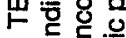

$\infty$ 으.드.

은 등 造造 
In several places of the exooplasmic cones direct continuity between the granulosa cell cytoplasm and the exooplasm seemed to exist thus forming true intercellular communications (fig 2).

The granulosa cells were also seen to give off transosomes in the exooplasmic cones (fig 2). The second type of exooplasmic extension was seen to form a large knobby protrusion (sometimes starting from an exooplasmic cone) into a granulosa cell (fig 4). A third smaller type, the so-called "protuberance" (probably corresponding to the description of Bellairs, $1965)$ also often originating from the exoo- plasmic cones was seen to invaginate into the neighbouring granulosa cell (fig 3). In or around the "complex mass" (Bellairs' denomination: 1965) of the granulosa cells, numerous fat spherules were occasionally seen (fig 5). With fixation method 1 the complex masses were sometimes seen to contain elements resembling nucleated red blood cells and with the size range of viral particles. No lipid material could be observed between the granulosa cells or between the granulosa cells and the basement membrane.

Dark granulosa cells could be detected locally after fixation method 2 (fig 6).

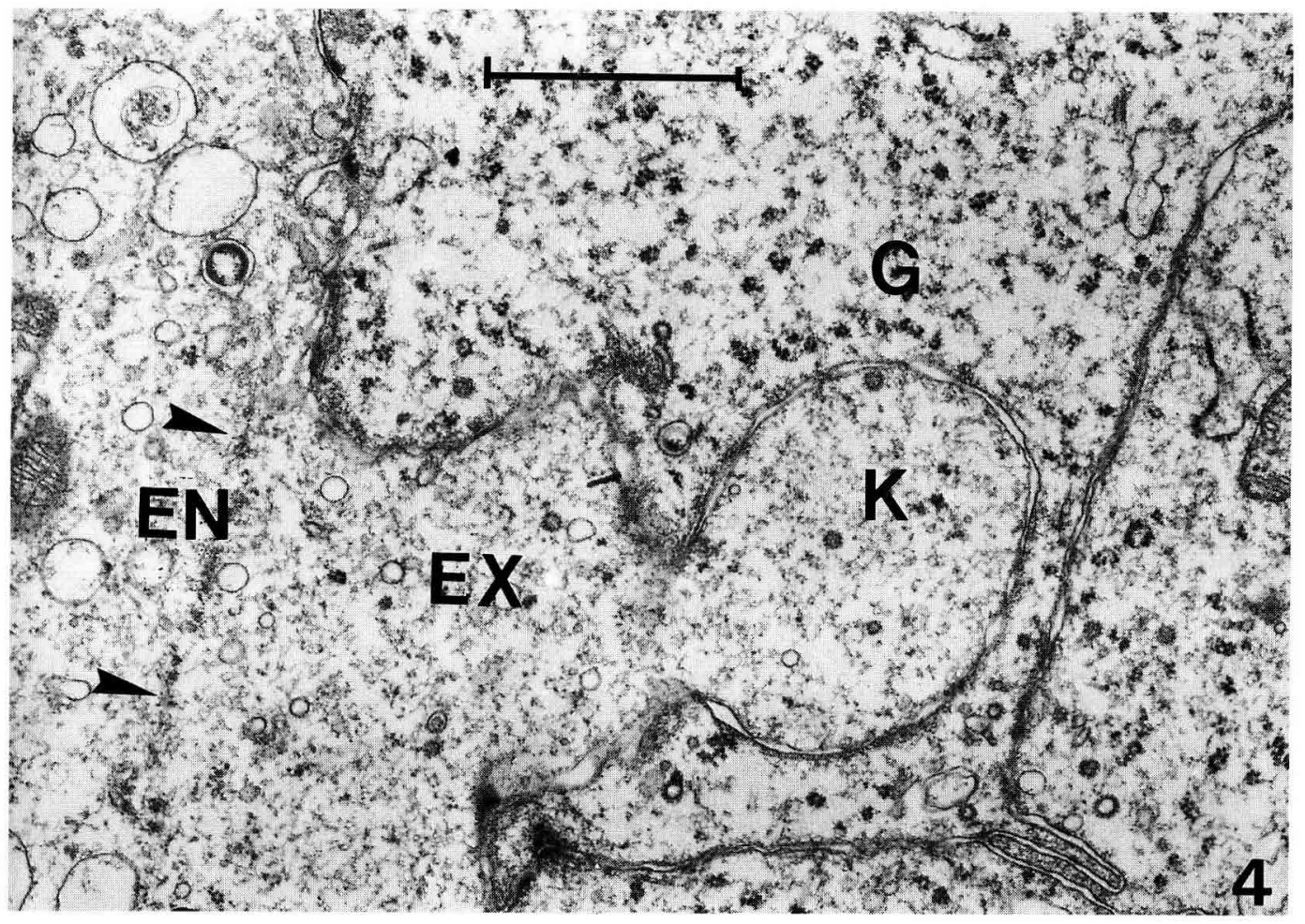

Fig 4. TEM micrograph of section through a large knobby protrusion $(K)$ coming from the exooplasm (EX) and deeply indented in the neighbouring granulosa cell (G); EN: endooplasm of prelampbrush oocyte; arrowheads indicate interrupted plane region of filaments; fixation method 1 . Scale bar: $1 \mu \mathrm{m}$; $\times 28000$. 


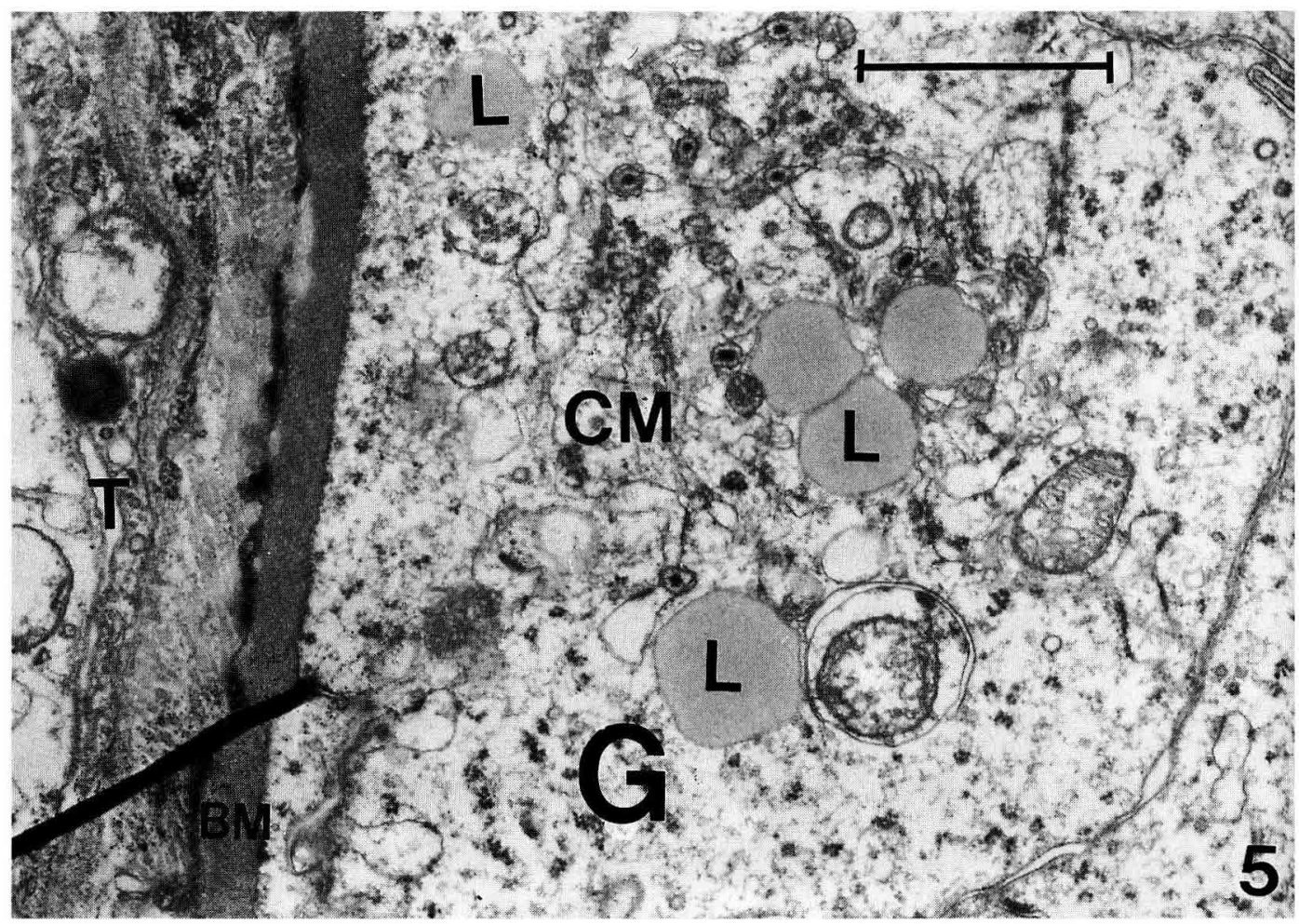

Fig 5. TEM micrograph of section through complex mass (CM) of granulosa cell (G) at the surface of prelampbrush oocyte; L: lipid granules; T: theca; BM: basement membrane; fixation method 1. Scale bar: $1 \mu \mathrm{m} \times 28000$.

These dark cells have a rather angular aspect with numerous tentacle-like extensions near the basement membrane, between the clear rounded granulosa cells and also extend to the exooplasmic cones of the oocyte.

Although the dark granulosa cells have a prominent nucleolus, their nucleus is smaller than that in the clear granulosa cells. The nuclear wall has an irregular outline and the nucleoplasm is as densely stained as the cytoplasm between the numerous vacuoles. The boundary between nucleus and cytoplasm is therefore not easily visible. This gives the cell a mouldy wood aspect. Sometimes the ooplasm of the prelampbrush oocyte was not wholly covered by granulosa cells and even extended to the basement membrane. After fixation method 2, the lipids were less well conserved.

In the ooplasm of some of the prelampbrush oocytes a voluminous body (partially surrounded by a cell membrane: trilaminar at high magnification) as large as a whole granulosa cell (and probably representing an engulfed granulosa cell) was seen. It seemed to be composed of remnants of 


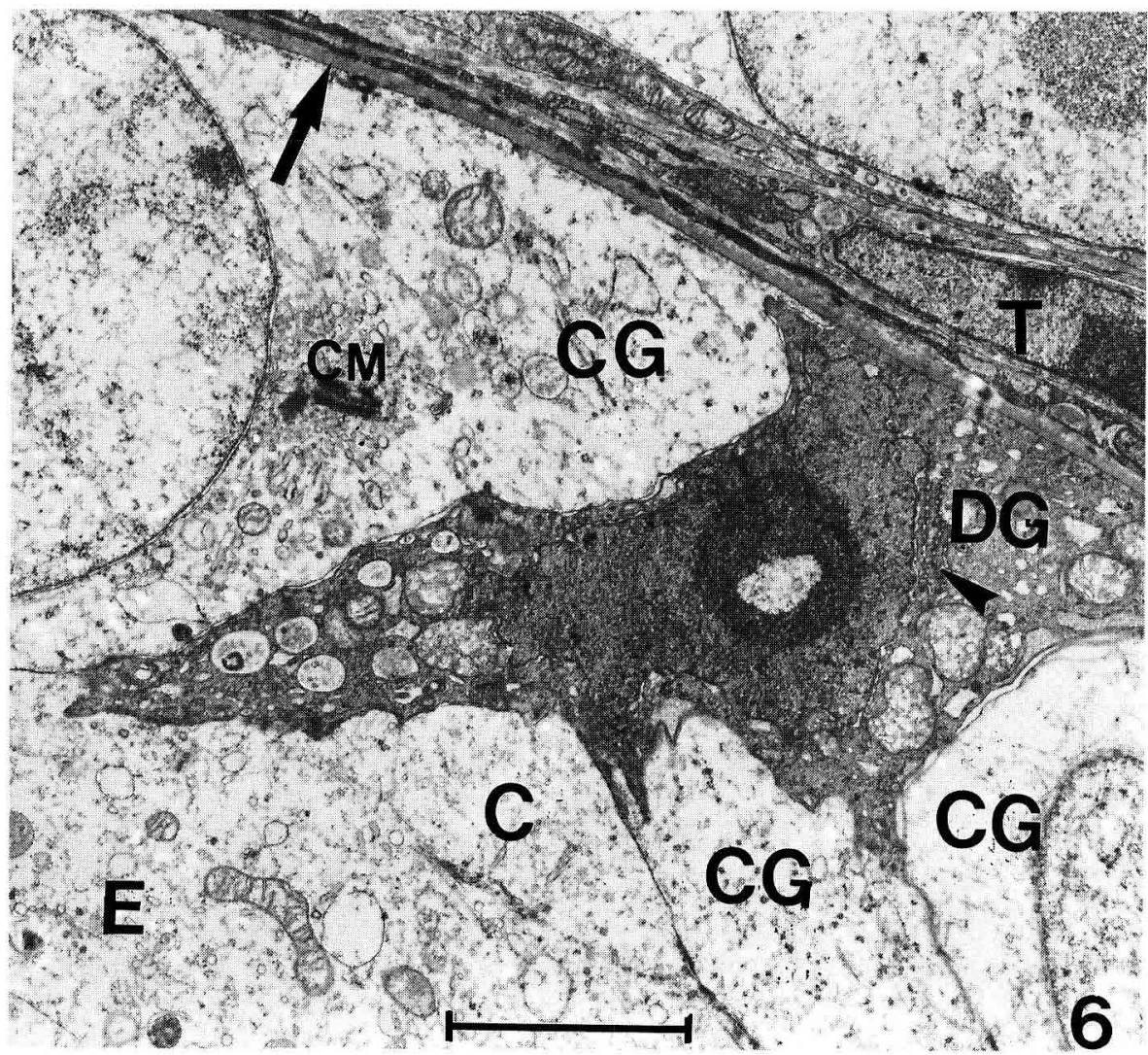

Fig 6. TEM micrograph of a section through the follicle wall of a prelampbrush oocyte after fixation method 2; the very dark granulosa cell (DG) pressed between 3 clear granulosa cells (CG) can be clearly seen. Note the angular aspect of the dark cell with tentacle-like extensions near the basement membrane, between the other granulosa cells and the exooplasmic cone (C) of the prelampbrush oocyte; E: oocyte endoplasm containing mitochondria. The nucleoplasm of the dark cell is very dense and the nuclear membrane has an irregular form (arrowhead indicates annulate lamellae close to the nuclear membrane); $\mathrm{T}$ : theca; arrow indicates basement membrane; $\mathrm{CM}$ : complex mass with paired centrioles and numerous small vesicles. Scale bar: $2 \mu \mathrm{m} ; \times 12000$.

cell organelles forming vacuoles and irregular clumps with variable aspect and diameter. A central part containing dense granular material and resembling a nuclear area could sometimes be observed.

\section{DISCUSSION AND CONCLUSION}

The present TEM study offers a clear view of granulosa cell and oocytal membranes and retains the lipids (after fixation method 
1: Callebaut, 1990). This can be explained by: i), the presence in the glutaraldehyde fixative of malachite green which retains phospholipids in the tissues (Teichmann et al, 1972; Lawton, 1989); and ii), the treatment with $70 \%$ alcohol immediately after the primary fixation which not only prevents solubilisation of some fixed proteins (Silverton and Anderson, 1961) but also of some lipids: cholesterol and triglycerides (Callebaut et al, 1991).

Since De Somer's report (1905) it has been known that the smallest follicles in the ovary of the adult chicken contain numerous lipid spheres grouped round the Balbiani complex. The origin of these lipid spheres is not known, but the following hypotheses may be considered: i), they may be synthesized by the oocyte (so-called endogenous yolk formation); ii), they may be formed in the granulosa cells and then transported into the ooplasm; iii), they may be formed from precursor material in the theca and pass between the granulosa cells; iv), they may come from plasma lipids which penetrate through the follicle wall.

In the present study morphological evidence was found for the second possibility, but the other hypotheses cannot be excluded. Earlier studies seemed to indicate that some components, such as Golgi bodies (Brambell, 1926), were transported from the granulosa cells to the ooplasm before the onset of the rapid oocytal growth period. In a recent study we also found electron microscopic evidence for the delivery of lipids by the granulosa cells to the superficial avian ooplasm in the largest follicles during their final yellow yolk assemblage (Callebaut, 1991a). According to Kemp (1958), intercellular bridges exist between the avian granulosa and the oocyte. By contrast, Press (1959) and Bellairs (1965) found no evidence for such intercellular bridges. In the present study howev- er, using a different method of fixation intercellular bridges were also seen.

Among vertebrates, true intercellular communications between granulosa cells and oocyte have been described by TEM only in squamate reptiles (lizards and snakes) (Ghiara and Filosa, 1966; Hubert, 1971; Neaves, 1971; Taddei, 1972; BouResli, 1974). These communications originate through a secondary fusion of the oocyte with the granulosa cells before they begin to differentiate into pyriform cells (Andreuccetti et al, 1978). Let us mention that the class Aves also belongs to a similar genome lineage as do the reptilian suborder of the Squamata, suggesting a common phylogenetic past (Ohno, 1970).

Dark granulosa cells have been described at some periods (different according to the fixative used) of avian follicular development (Holl, 1890; Brambell, 1926; Marza and Marza, 1935; Press, 1964). They have been considered as degenerating cells (Brambell, 1926; Bellairs, 1965; Chalana and Guraya, 1980; Guraya, 1989). However, the present study suggests that these angular cells with long tentacular processes between the neighbouring granulosa cells and extending from the basement membrane to the oocyte have a holding or supporting function, as has already been suggested by Holl (1890). We have also described them at more advanced stages of follicular development (Callebaut, 1991b). As was the case in the lampbrush and beginning postlampbrush stages (Callebaut et al, 1981), during the prelampbrush stage of the quail oocyte we could also discern 3 major ooplasmic zones by the trypan blue-induced fluorescence method (Callebaut and Sijens, 1985). The exooplasmic zone described here where uptake of material from the granulosa cells seems to occur probably corresponds to the narrow most superficial unlabelled ooplasmic zone seen 
after trypan blue administration. It probably functions as an oocyte transit compartment and also exists during the lampbrush stage (Callebaut, 1991b).

\section{ACKNOWLEDGMENTS}

I thank C De Chepper for excellent technical assistance and $W$ Walscharts for typing the manuscript. I also thank $L$ Andries for valuable suggestions and Prof D Scheuermann and collaborators (RUCA, histological laboratory) for the use of their TEM. This study was supported by grant 3.0037 .90 from the NFWO of Belgium.

\section{REFERENCES}

Andreucetti P, Taddei C, Filosa S (1978) Intercellular bridges between follicles cells and oocyte during the differentiation of follicular epithelium in Lacerta sicula. J Cell Sci 33, 341-350

Bellairs R (1965) The relationship between oocyte and follicle in the hen's ovary as shown by electron microscopy. $J$ Embryol Exp Morphol 13, 215-233

Bellairs R (1967) Aspects of the development of yolk spheres in the hen's oocyte, studied by electron microscopy. J Embryol Exp Morphol 17, 267-281

Brambell FWR (1926) The oogenesis of the fowl (Gallus bankiva). Phil Trans $R$ Soc Lond 214, 113-148

Bou-Resli M (1974) Ultrastructural studies on the intercellular bridges between the oocyte and follicle cells in the lizard AcanthodactyIus scuttelatus Hariji. Anat Entwickl Gesch 143, 239-254

Callebaut M (1973) Correlation between germinal vesicle and oocyte development in the adult Japanese quail (Coturnix coturnix japonica). J Embryol Exp Morphol 29, 145-157

Callebaut M (1984) Evolution of paranuclear sudanophilic organelles in quail oocytes. IRCS Med Sci 12, 1040-1041

Callebaut M (1990) Improved visualization of ultrastructural components in avian ovarian granulosa basement membrane. Cell Biol int Rep 14/7, 653-658

Callebaut M (1991a) Electron microscopic evidence for the delivery of lipids by the granulosa cells to the superficial avian ooplasm. Eur Arch Biol 102 (in press)

Callebaut M (1991b) Pyriform-like and holding granulosa cells in the avian ovarian follicle wall. Eur Arch Biol 102 (in press)

Callebaut M, Harrisson F, Vakaet L (1981) Peripheral avian yolk assemblage and its persistence in the blastoderm studied by trypan blue-induced fluoresence. Anat Embryol 163, 55-69

Callebaut M, Sijens RJ (1985) Trypan blueinduced fluoresence in adult quail oocytes during the prelampbrush and early lampbrush stage. IRCS Med Sci 13, 920-921

Callebaut M, D'Herde K, Hermans N, Van Nassauw $L$ (1991) Localization and transport of lipids in the avian ovarian follicular layers and the structural relationship of theca and granulosa to the basement membrane. J Morphol (in press)

Chalana R, Guraya S (1980) Morphological and histochemical changes in the follicular epithelium during follicular growth in the crow Corvus splendens. Proc Ind Acad Sci (Anim Sci) 89, 133-140

De Somer E (1905) Les premiers stades de la vitellogenèse dans l'ovule de la poule. Ann Soc Med Gand 85, 55-63

Ghiara G, Filosa S (1966) Relievi strutturali e funzionali sull' epitelio follicolare delgi ovociti in accrescimento di un retile. Boll Zool 33, 133-135

Guraya S (1989) Ovarian follicles in reptiles and birds. In: Zoophysiology. Springer Verlag, Berlin, vol 24

Holl M (1890) Uber die Reifung der Eizelle des Huhn's. Sitzungsber K Akad Wiss (abt 3) 99, 311-370

Hubert J (1971) Étude histologique et ultrastructurale de la granulosa à certains stades de développement du follicule ovarien chez un lézard Lacerta vivipara Jacquin. $Z$ Zellforsch $115,46-59$

Kemp N (1958) Protoplasmic bridges between oocytes and follicle cells in vertebrates. Anat $\operatorname{Rec} 130,324-325$ 
Klosterman L (1987) Ultrastructural and quantitative dynamics of the granulosa of ovarian follicles of the lizard Gerrhonotus cabuleus. J Morphol 192, 125-144

Lawton J (1989) An investigation of the fixation and staining of lipids by a combination of malachite green or other triphenylmethane dyes with glutaraldehyde. J Microsc 154, 83-92

Marza V, Marza R (1935) The formation of the hen's egg. Parts I-IV. $Q J$ Microsc Sci 78, 134-189

Neaves W (1971) Intercellular bridges between follicle cells and oocyte in the lizard Anolis carolinensis. Anat Rec 170, 285-302

Ohno S (1970) Evolution by Gene Duplication. Springer Verlag, Berlin

Press N (1959) An electron microscope study of a mechanism for the delivery of follicular cytoplasm to an avian egg. Exp Cell Res 18, 194-196

Press N (1964) An unusual organelle in avian ovaries. J Ultrastruct Res 10, 528-546
Rahil K, Narbaitz R (1973) Ultrastructural studies on the relationship between follicular cells and growing oocytes in the turtle Pseudemys scripta elegans. J Anat 115, 175-186

Reynolds E (1963) The use of lead citrate at high $\mathrm{pH}$ as an electron-opaque stain in electron microscopy. J Cell Biol 17, 208-212

Silverton R, Anderson MJ (1961) Handbook of Medical Laboratory Formulae. Butterworths, London

Taddei C (1972) Significance of pyriform cells in ovarian follicle of Lacerta sicula. Exp Cell Res 72, 562-566

Teichmann R, Fujimoto M, Yanagimachi $R$ (1972) A previously unrecognized material in mammalian spermatozoa as revealed by malachite green and pyronine. Biol Reprod 7, 73-81

Wyburn GM, Johnston H, Aitken R (1966) Fate of the granulosa cells in the hen's follicle. $Z$ Zellforsch $72,53-65$ 